\title{
Population and reproductive parameters of the red-tailed catfish, Phractocephalus hemioliopterus (Pimelodidae: Siluriformes), from the Xingu River, Brazil
}

\author{
Tiago Magalhães da Silva Freitas ${ }^{1}$ and Luciano Fogaça de Assis Montag ${ }^{2}$
}

A field study of the sex ratio, length-weight ratio, body size at first gonadal maturation, and the breeding season of the redtailed catfish, Phractocephalus hemioliopterus, was carried out in the region of the middle Xingu River in the eastern Amazon basin. The fish were sampled quarterly from September 2012 to January 2014 using gillnets and long lines. The sex ratio was balanced, and while males and females were similar in standard length, the females were heavier than the males, on average. The males presented negative allometric growth, and the females, isometric growth. The estimated size at first maturity was $77.8 \mathrm{~cm}$. The variation in the gonadosomatic index and the greater frequencies of mature specimens indicated a reproductive peak at the beginning of the high-water (flood) period. As $P$. hemioliopterus is an important commercial fish, our findings will contribute to the future development of effective conservation and management strategies, such as minimum catch size and a close season that is appropriate for the region. These data will also provide important insights for the evaluation of potential impacts on the biology of this fish resulting from the construction of Belo Monte dam.

Keywords: Amazon basin, Breeding season, Fishery, Gonadal maturity, Growth pattern.

Um estudo de campo sobre a proporção sexual, relação peso-comprimento, tamanho de primeira maturação gonadal e o período reprodutivo da pirarara, Phractocephalus hemioliopterus foi realizado na região do Médio Rio Xingu, na Amazônia oriental. Os espécimes foram coletados trimestralmente entre setembro de 2012 e janeiro de 2014, utilizando redes malhadeiras e espinheis. A proporção sexual foi balanceada, e machos e fêmeas foram equivalentes quanto ao comprimento padrão, mas fêmeas foram mais pesadas do que machos. Crescimento alométrico negativo foi evidenciado para machos e crescimento isométrico para fêmeas. O tamanho estimado de primeira maturação sexual foi igual a $77,8 \mathrm{~cm}$. A variação do índice gonadossomático e a maior frequência de indivíduos maduros evidenciaram uma maior atividade reprodutiva no começo do período de águas altas (enchente). Considerando P. hemioliopterus como uma espécie de interesse comercial, as informações aqui apresentadas poderão ser uteis para um futuro plano de conservação e manejo como o estabelecimento de um tamanho mínimo de captura e período de defeso para a região. Além disso, poderá ser útil para avaliar potenciais impactos na biologia dos peixes em decorrência das mudanças ambientais provocadas pela construção da barragem de Belo Monte.

Palavras-chave: Bacia Amazônica, Maturação Gonadal, Padrão de crescimento, Período reprodutivo, Pesca.

\section{Introduction}

The family Pimelodidae comprises more than one hundred valid species of freshwater fish (Frickle et al., 2019), which are all endemic to the Neotropics, with the highest diversity being found in the Amazon, Paraná and Orinoco basins, and the principal rivers of the Guianas (Lundberg, Littmann, 2003). The adult fishes of this family vary considerably in body length, ranging from $20 \mathrm{~cm}$ to over two meters. Many of the larger pimelodid species are long-distance migrators (Godinho, Kynard, 2009; Hauser et al., 2018) that travel considerable distance to spawn, and are an important source of animal protein for many human populations throughout tropical South America. These fish are mainly species of the genera Brachyplatystoma and Pseudoplatystoma (Barthem, Goulding, 1997; Barthem et al., 2017; Pérez, Fabré, 2018).

The giant red-tailed catfish, Phractocephalus hemioliopterus (Bloch, Schneider, 1801), known as the "pirarara" in Brazil, is widely distributed in the Amazon and Orinoco basins. This species is a medium-distance migrator, typically traveling $100-1,000 \mathrm{~km}$, is also one of the most important species for sport and commercial fisheries (Carolsfeld et al., 2003; Barletta et al., 2015; Mesquita,

${ }^{1}$ Faculdade de Ciências Naturais, Campus Universitário do Marajó-Breves, Universidade Federal do Pará, Alameda IV, 3418, Parque Universitário, 68800-000 Breves, PA, Brazil. freitastms@gmail.com, Ohttps://orcid.org/0000-0003-3203-3408 (corresponding author) ${ }^{2}$ Laboratório de Ecologia e Conservação, Instituto de Ciências Biológicas, Universidade Federal do Pará, Rua Augusto Corrêa, 01, Guamá, 66075-110 Belém, PA, Brazil. lfamontag@gmail.com, Dhttps://orcid.org/0000-0001-9370-6747 
Isaac-Nahum, 2015). The potential yield of the species in the Amazon region was estimated to be almost 900 tons per year (Barthem, Goulding, 2007). Despite this interest, the species has not yet been assessed for the IUCN Red List of Threatened Species (IUCN, 2019), even though its natural stocks may be at risk from increasing of human interference in recent decades, in particular, the damming of the major rivers of the Amazon basin (Winemiller et al., 2016; Forsberg et al., 2017), which threaten local biological cycles. In general, impoundment alters the local hydrological regime, including the intensity and periodicity of the flood pulse, which is an important trigger for final oocyte maturation, as well as disrupting migration routes to spawning areas and feeding grounds (Vazzoler, 1996; Antonio et al., 2007).

In the context of these effects of river impoundment, studies of the reproductive biology of fishes constitute an essential tool for the better understanding of population dynamics related to the seasonal variation in the environmental factors observed in aquatic ecosystems (Freitas et al., 2015; Barbosa et al., 2018). In the Amazon basin, this seasonality is derived naturally from the hydrological oscillations of the flood pulse (Junk et al., 1989), which plays a significant role in the maturation of fish gonads, the spawning season, and larval development (Goulding, 1980; Zeug, Winemiller, 2008).

Despite the ecological and economic relevance of $P$. hemioliopterus, few data are available on this species, and the limited number of available studies have focused on its piscivorous feeding habits (Barbarino-Duque, Winemiller, 2003), parasitology (De Chambrier et al., 2005), lengthweight and length-length relationships (Giarrizzo et al., 2015), biotelemetry (Hahn et al., 2015), and cytogenetics (Swarça et al., 2017), and no studies have focused on the reproductive biology of the species. Given this, the present study investigated the population parameters and reproductive patterns of $P$. hemioliopterus in the region of the middle Xingu River, in the eastern Amazon basin. The study evaluated the sex ratio, length-weight relationship, size at first maturity, and breeding season of $P$. hemioliopterus in this region, where one of the largest hydropower installations in South America, the Belo Monte Dam, was recently constructed (Winemiller et al., 2016). The results of this study provide crucial data from the period prior to the impoundment and serve as a baseline for further comparisons and decision-making on the management of local fishery stocks.

\section{Material and Methods}

Sampling sites. The Xingu River is a clear-water system characterized by low $\mathrm{pH}$, conductivity, and suspended solid concentrations, and is one of the most important rightbank tributaries of the Amazon River. In the region of the middle Xingu River (near the city of Altamira; $3^{\circ} 12^{\prime} 52^{\prime}$ " S, 52 $11^{\prime} 23$ " W) (Fig. 1), the climate is tropical hot and humid, Am type in the Köppen-Geiger classification (Peel et al., 2007). The predominant vegetation is typical lowland Amazon rainforest (Barbosa et al., 2018). The annual fluviometric variation recorded on the river can be divided into four distinct hydrological periods: the dry (SeptemberNovember), filling (December-February), flood (MarchMay), and receding (June-August) (see Barbosa et al., $2015 ; 2018$ ). The fluviometric data were obtained from the Brazilian National Waters Agency ("Agência Nacional de Águas", ANA, 2018).



Fig. 1. Study area on the middle Xingu River in Pará, Brazil. The black dots represent the sampling sites, and the arrows indicate the direction of the water flow. 
Collection of fish specimens. Specimens of $P$. hemioliopterus were collected quarterly from September 2012 to January 2014, using gillnets of ten different mesh sizes (20-180 mm stretch meshes), and long lines with 30 hooks (sizes 120 and 140 ), cast under the guidance of a local fisherman and set for twelve hours per day (18:00 h to 06:00 h). Fish were sampled according to the environmental monitoring guidelines of the Belo Monte Dam (for further details of the sampling methods, see Barbosa et al., 2015). The specimens captured were measured to determine their standard length $\left(\mathrm{S}_{\mathrm{L}} ; 0.1\right.$ $\mathrm{cm})$, and weighed to establish total mass $\left(\mathrm{T}_{\mathrm{M}} ; 0.1 \mathrm{~g}\right)$ and gonadal mass $\left(\mathrm{G}_{\mathrm{M}} ; 0.1 \mathrm{~g}\right)$. We determined the sex and gonadal maturation of each specimen through a visual macroscopic analysis of the gonads, based on the protocol of Vazzoler (1996), which classifies the fish as stage I (immature); stage II (maturing); stage III (mature); and stage IV (at rest or empty). Voucher specimens were fixed in $10 \%$ formalin for $48 \mathrm{~h}$, transferred to $70 \%$ ethanol for storage, and deposited in the Laboratory of Ichthyology of Altamira (in Portuguese 'LIA') in Altamira (Pará, Brazil) under numbers LIA 389 and LIA 790. The Ethics Committee of the Universidade Federal do Pará approved the collection and conservation of the fish specimens (protocol CEUA n ${ }^{\circ} 8293020418$ ).

Data analysis. Sex ratio and length-weight relationship. The bias in the sex ratio during the different study periods was evaluated using Chi-square $\left(\mathrm{X}^{2}\right)$. Differences in body length and weight were evaluated by the $t$ test. The length-weight relationship (LWR) adhered to the model first proposed by Järvi (1920) (see Froese, 2006), where $T_{M}$ is the total mass of the specimen and $S_{L}$ is its standard length. Parameter $a$ is the coefficient of proportionality, and $b$ is the coefficient of allometry, where $b$ can also be interpreted as the fish growth type (Froese, 2006). After pooling the LWRs for the two sexes, sexual differences in growth patterns were assessed based on the comparison of length residues ([observedpredicted $]$ /predicted) using the $t$ test (see Fontoura, Conter, 2008; Freitas et al., 2016). When differences between the sexes were identified, the LWRs were calculated separately for males and females. To define the growth type of $P$. hemioliopterus, the $b$ values were evaluated using a $t$ test, comparing the observed value with a hypothetical $b$ value of 3, which defines isometric growth (Froese, 2006), that is, when length and weight vary proportionately. Negative allometry occurs when body length increases at a faster rate than weight $(b<3)$, while positive allometry occurs when weight increases at a faster rate than body size $(b>3)$ (Froese, 2006).

First sexual maturation. Size at first sexual maturation $\left(\mathrm{L}_{50}\right)$ was estimated based on the logistic equation of Trippel, Harvey (1991), where $\mathrm{P}=$ the proportion of reproductive adults in each size class, $\mathrm{A}=$ the asymptote of the curve (A $=1), r=$ the rate of change between non- reproductive and reproductive individuals, $\mathrm{S}_{\mathrm{L}}=$ the standard length $(\mathrm{cm})$ in the size classes, and $\mathrm{L}_{50}=$ the size $(\mathrm{cm})$ at which $50 \%$ of the individuals reach sexual maturity. The gonadossomatic index (GSI) was used for this analysis, and was obtained through the formula; where $G_{M}$ is the weight of the gonads $(\mathrm{g})$ and $\mathrm{T}_{\mathrm{M}}$ is the total mass of the individual $(\mathrm{g})$. These values were then transformed into a percentage of the maximum recorded value, and the specimens were binarized as reproductive or non-reproductive. As proposed by Fontoura et al. (2009), all individuals with GSI values equal to or greater than a certain percentage of the maximum GSI were considered to be involved in the reproductive process. Here, we applied a criterion of $5 \%$ to determine the reproductive status of a specimen, that is, any individual with a GSI of less than $5 \%$ of the maximum value recorded was classified as non-reproductive, with all other individuals $(>5 \%$ of the maximum GSI) being considered reproductive. The equation parameters were estimated from the data set organized in 10 $\mathrm{cm}$ length classes using a non-linear regression routine run in R (R Development Core Team, 2015). To avoid possible sampling effects, the $\mathrm{L}_{50}$ analysis was run with both sexes pooled.

Reproductive activity. The breeding season was determined through the seasonal variation in the gonadosomatic index (GSI) recorded during each study period, also for the pooled data (both sexes). Higher GSI values indicate greater reproductive activity. The GSI values were adjusted using a sinusoidal function, as proposed by Fontoura, Agostinho (1996) (applied by Freitas et al., 2011), which describes seasonal (cyclic) variation based on the formula: where $\mathrm{M}=$ global mean GSI, A = amplitude of the variation in GSI, Frq $=$ unit of time in which the events were measured $(\mathrm{Frq}=12$ when the time is measured in months), $\mathrm{t}$ (time) $=$ numerical time scale (here, January $=1$, February $=2$, March $=3 \ldots$ December $=12$ ), and $\mathrm{f}$ (phase) $=$ the difference between the baseline time (zero) and the time with the maximum mean GSI value (representing the sinusoid). In this case, the phase also represents the month of the year with the largest estimated GSI values. A coefficient of determination $\left(\mathrm{R}^{2}\right)$ was calculated for the sinusoidal model by the ratio of the sum of the squares of the residuals to the total sum of squares, with the $p$-values being obtained using a significance test based on the F statistic. All the parameters of the sinusoidal function were estimated by using the Solver tool of Microsoft Office Excel ${ }^{\circledR} 2010$. The relative frequencies of the gonadal maturation stages and local fluviometric levels were recorded in each study period. A 5\% significance level was considered in all analyses (Zar, 2010).

\section{Results}

A total of 154 P. hemioliopterus specimens were collected during the study period, of which, 66 were male and 88 were female. The sex ratio was balanced in most study periods (Tab. 1), but biased significantly toward the females in the dry season of $2012\left(\chi^{2}=4.296, p=0.038\right)$ and toward the males in the filling season of $2014\left(\chi^{2}=4.416, p=0.036\right)$. 
Tab. 1. Sex ratio of the red-tailed catfish, Phractocephalus hemioliopterus, specimens collected from the Xingu River in Pará, Brazil. *indicates a significant difference between males and females.

\begin{tabular}{lccccccc}
\hline \multirow{2}{*}{ Sex } & 2012 & \multicolumn{4}{c}{2013} & \multicolumn{3}{c}{2014} & \multirow{2}{*}{ Total } \\
\cline { 2 - 7 } & Dry & Filling & Flood & Receding & Dry & Filling & \\
\hline Males & 22 & 12 & 7 & 8 & 6 & 11 & 66 \\
Females & 40 & 9 & 12 & 13 & 8 & 6 & 88 \\
Chi-square $\left(\chi^{2}\right)$ & 4.296 & 1.018 & 3.553 & 2.873 & 1.018 & 4.416 & 1.018 \\
$\mathrm{p}$ & $0.038^{*}$ & 0.313 & 0.059 & 0.090 & 0.313 & $0.036^{*}$ & 0.313 \\
\hline
\end{tabular}

Body length did not vary significantly between the sexes $(t=1.144, \mathrm{p}=0.096)$. The mean total length of the males was $63.5 \pm 20.4 \mathrm{~cm}$ (range $26.5-119.0 \mathrm{~cm}$ ) and that of the females was $68.0 \pm 21.9 \mathrm{~cm}$ (range 27.3-125.4 cm). By contrast, females were significantly heavier than males $(t=$ $1.860, \mathrm{p}=0.033$ ), with a mean weight of $8.7 \pm 8.7 \mathrm{~kg}$ (range $0.6-40.0 \mathrm{~kg}$ ) compared with $6.7 \pm 6.1 \mathrm{~kg}$ (range $0.7-26.6 \mathrm{~kg}$ ) in the males.

The analysis of the LWR revealed a clear gender bias in growth patterns $(t=1.921, \mathrm{p}=0.029)$, which indicated the need for the application of distinct equations. For the males, the LWR was established through the equation $\mathrm{T}_{M}=$ $0.029 * \mathrm{~S}_{\mathrm{L}}{ }^{2.830}\left(\mathrm{R}^{2}=0.956\right)$ (Fig. 2a), while for females, the formula was $\mathrm{T}_{\mathrm{M}}=0.024 * \mathrm{~S}_{\mathrm{L}}{ }^{2.971}\left(\mathrm{R}^{2}=0.979\right.$ (Fig. 2b). The LWR indicated negative allometric growth in the males $(b$ $=2.830, t=2.984, \mathrm{p}=0.002)$ and isometric growth in the females $(\mathrm{b}=2.971, t=0.426, \mathrm{p}=0.336)$.

\section{$\mathbf{a}$}

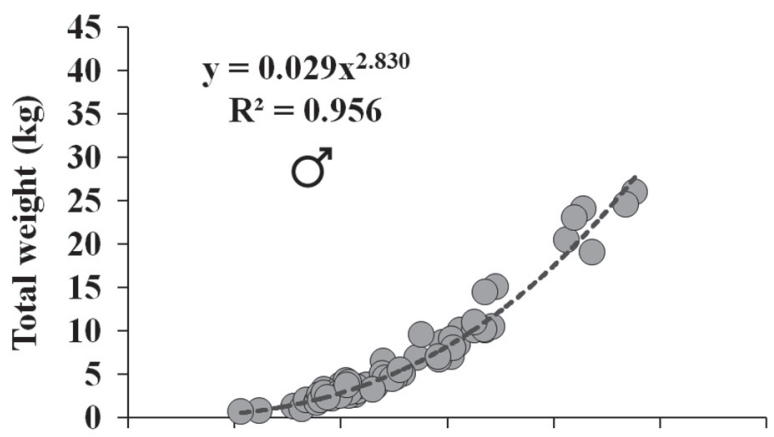

b

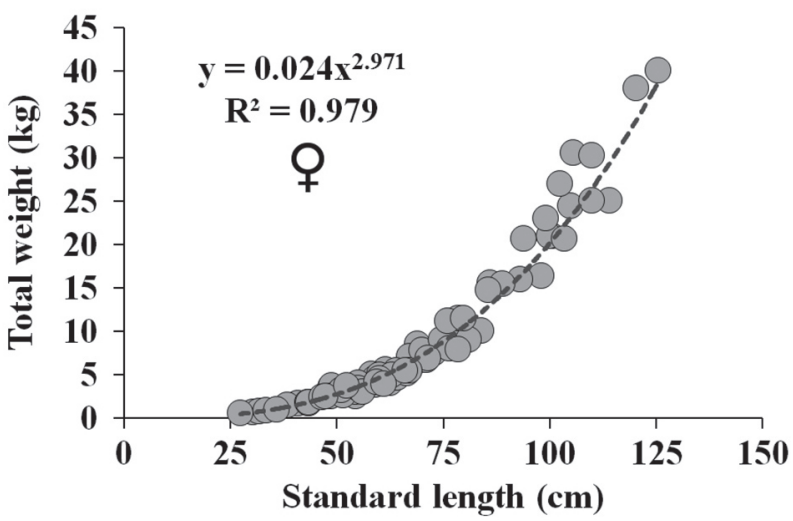

Fig. 2. Length-weight relationship of the red-tailed catfish Phractocephalus hemioliopterus specimens collected from the Xingu River in Pará, Brazil. a. males; and b. females.
To avoid diluting the number of adults specimens (15 males and 21 females) among the different length classes considering the $5 \%$ criterion of the maximum GSI - we pooled the two sexes to estimate the size at the first sexual maturation (L50) of $P$. hemioliopterus, which was $77.8 \mathrm{~cm}$ (lower limit = $76.3 \mathrm{~cm}$; upper limit $\left.=79.3 \mathrm{~cm} ; \mathrm{R}^{2}=0.996\right)($ Fig. 3).

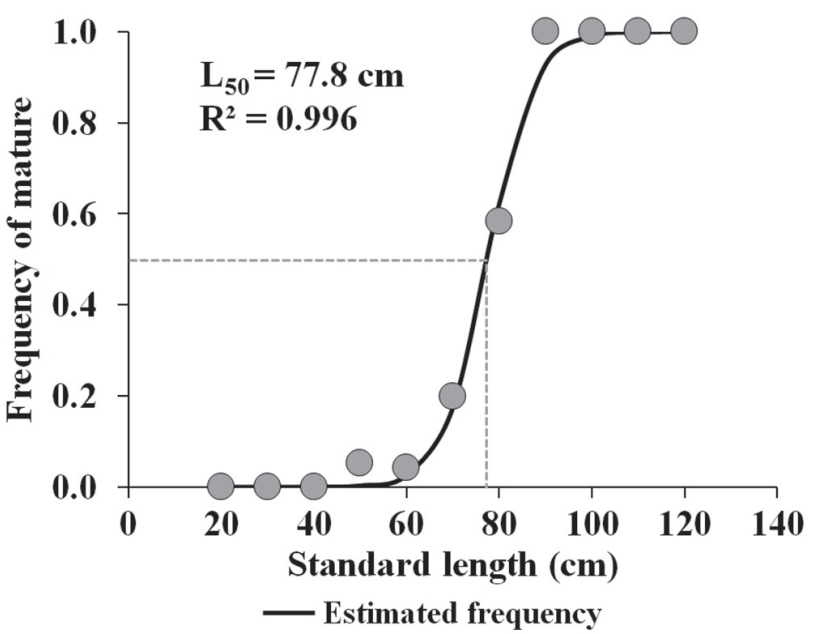

Fig. 3. Size at first sexual maturity in the red-tailed catfish Phractocephalus hemioliopterus specimens collected from the Xingu River in Pará, Brazil.

Seasonally, we recorded a reproductive peak (pooled data) in the filling period of $2014(\mathrm{p}=0.042, \mathrm{~F}=6.323$, Fig. 4), with a mean GSI of 3.07. The phase parameter of the sinusoidal equation $(f=1.38)$ indicated that reproductive activity occurs primarily between January and February (see Tab. 2). We also observed a higher frequency of individuals in the mature and rest gonadal stages during the filling season of 2014 (Fig. 5), which corroborates the sinusoidal analysis.

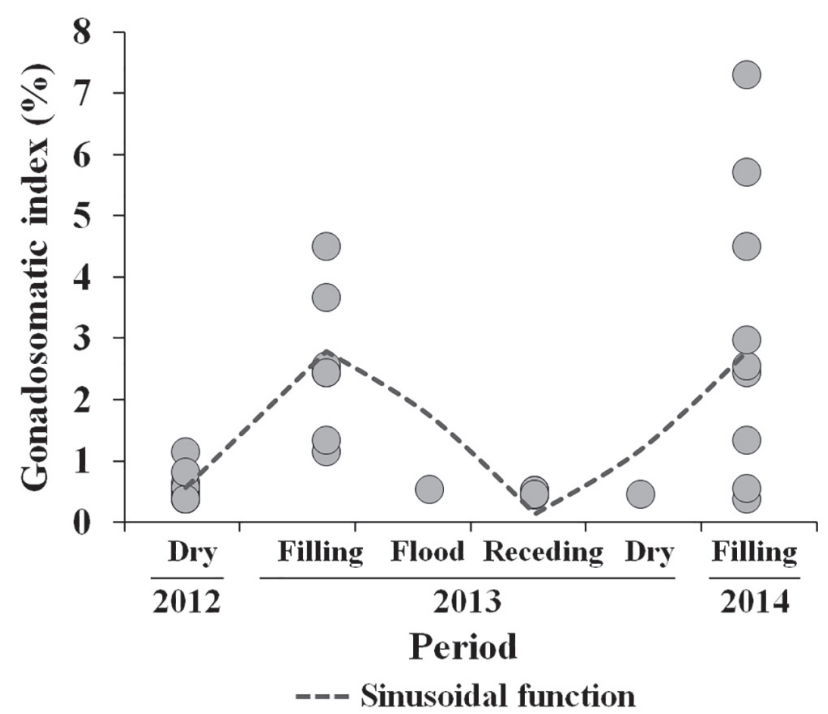

Fig. 4. Variation of the gonadosomatic index (GSI) of adult (reproductive) red-tailed catfish Phractocephalus hemioliopterus specimens collected from the Xingu River, in Pará, Brazil. 
Tab. 2. Parameters of the sinusoidal equation for the Gonadossomatic Index (GSI) values recorded for the redtailed catfish, Phractocephalus hemioliopterus, specimens collected from the Xingu River in Pará, Brazil. *indicates a seasonal trend in the curve.

\begin{tabular}{lc}
\hline Parameters & Pooled sample \\
\hline Amplitude $(A)$ & 1.354 \\
Mean $(M)$ & 1.463 \\
Phase $(f)$ & 1.385 \\
$\mathrm{R}^{2}$ & 0.449 \\
P value & $0.042^{*}$ \\
\hline
\end{tabular}

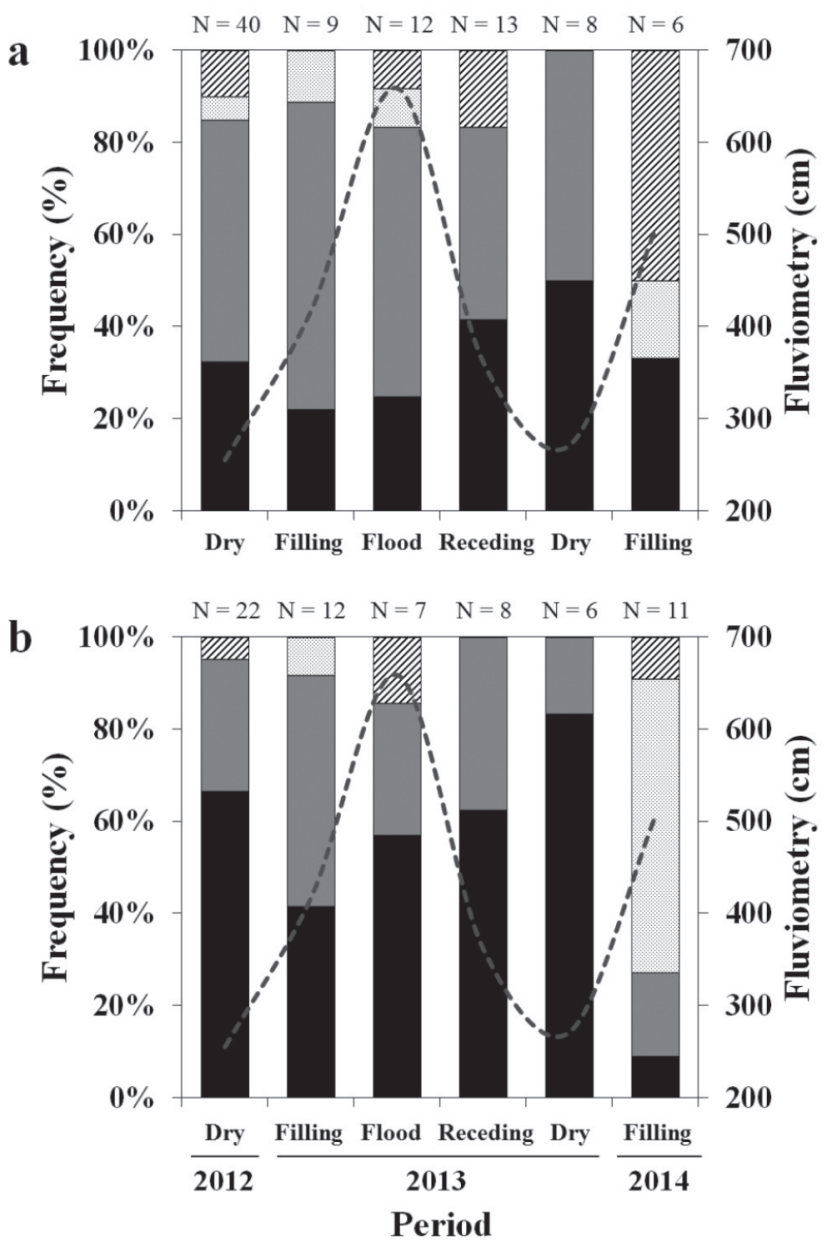

Immature $\square$ Maturing $\square$ Mature Rest

Fig. 5. Relative frequency (\%) of the different gonadal maturation stages of the red-tailed catfish Phractocephalus hemioliopterus specimens collected from the Xingu River in Pará, Brazil. a. males; and b. females.

\section{Discussion}

The present study determined the sex ratio, growth parameters, first sexual maturation, and reproductive season of Phractocephalus hemioliopterus from the middle Xingu River. No bias was found in the sex ratio for the study period as a whole, although a female bias was recorded during the dry periods, and a male bias during the filling period. Veloso-Junior et al. (2014) observed cohorts separated by sex and season in the pimelodid Pimelodus pohli Ribeiro, Lucena, 2006, and Figueiredo et al. (2018) also observed this pattern in other siluriforms. The results of the present study indicate that $P$. hemioliopterus may be segregated by sex with peaks of reproductive activity.

Sexual dimorphism was found in P. hemioliopterus, and has also been recorded in other pimelodids (Paschoalini et al, 2013; Suzuki et al., 2013; Barzotto et al., 2017). While the length did not vary between sexes, the female $P$. hemioliopterus were heavier than the males, presumably due to their greater energetic investment in the reproductive process, in particular, the production of eggs (Bromley, 2003; Prudente et al., 2014; Barneche et al., 2018). This pattern is relatively common in fish, given that the fertility of the female increases with body size (Bisazza, Pilastro, 1997; Murua, Saborido-Rey, 2003).

The negative allometry recorded in the LWR of the males indicates that their body length grows faster than their weight, whereas the females presented isometric growth. These sexual differences in growth patterns can also be related to reproductive strategies, that is, the faster growth in length would allow males to mature earlier, and then compete more effectively with other males for sexual partners (García-Vásquez et al., 2009; Freitas et al., 2015).

The $\mathrm{L}_{50}$ estimated for $P$. hemioliopterus was standard length of almost $80 \mathrm{~cm}$. Given the small number of adult specimens available in the present study, the size at first sexual maturity was estimated for males and females together. A much larger number of adult specimens would be recommended for the reliable determination of body size at first sexual maturation for each sex separately. However, our $\mathrm{L}_{50}$ is consistent with the values recorded for $P$. hemioliopterus from Bolivian river basins by Sarmiento et al. (2014), who established that maturation occurred at a length of $65-85 \mathrm{~cm}$. As the $\mathrm{L}_{50}$ value indicates the body size at which $50 \%$ of the individuals are new recruits, this value provides important insights for fish stock management, in particular, the definition of a minimum catch size, which would allow smaller fish to reach reproductive age (in this case, based on their body length). The $\mathrm{L}_{50}$ value obtained here for P. hemioliopterus is in agreement with Brazilian national and state legislation, which determine a minimum capture size of $80 \mathrm{~cm}$ for $P$. hemioliopterus in the Tocantins-Araguaia river basins (Brasil, 2011a; 2011b), $90 \mathrm{~cm}$ for individuals caught in the Brazilian state of Mato Grosso (Tiago, 2011), and 70 $\mathrm{cm}$ for the Colombian Amazon basin (Carolsfeld et al., 2003). No specific legislation applies to the Xingu River, however, which is preoccupying for the preservation of local aquatic biodiversity. This information is useful to prevent overfishing and the depletion of natural stocks by defining an effective cut-off size for fishery exploitation (Trippel, 1995; Hauser et al., 2018). 
The red-tailed catfish presented a peak in reproductive activity (as indicated by the GSI values and the increased frequency of mature individuals) at the beginning of the filling period. This period favors the reproduction of many fish species (Bailly et al., 2008), through the inundation of the flood plain and adjacent forests, providing new habitats for feeding and nurseries (Goulding, 1980). Many pimelodid fish are known to migrate several hundreds of kilometers to spawn (Barthem et al., 2017), and P. hemioliopterus appears to migrate as the water level is rising (Carolsfeld et al., 2003), which coincides with the timing of the breeding season recorded here. The reproductive behavior of $P$. hemioliopterus is still unclear, but the species is not captured in large schools, and probably migrates to spawn in the white-water rivers of the Amazon floodplain, given that juvenile specimens have never been registered in black or clear-water rivers (Barthem, Goulding, 2007).

A number of authors have also recognized the importance of the flood pulse for the reproduction of pimelodids (Holzbach et al., 2009; Suzuki et al., 2013; Barzotto et al., 2017). In the Amazon, in particular, many high-value species that migrate hundreds of kilometers in response to the seasonal flood pulse (e.g. P. hemioliopterus) will be threatened seriously by environmental changes driven by human interference, such as river impoundment (Winemiller et al., 2016; Barthem et al., 2017; Forsberg et al., 2017). This abrupt and permanent intervention in the characteristics of physical habitats may affect the reproductive and recruitment patterns of most fish species (Agostinho et al., 2004). In particular, migratory fish, like $P$. hemioliopterus, may be prevented from completing their reproductive migrations due to the obstruction of the river, which impedes the fish from reaching suitable spawning locations (Antonio et al., 2007; Pelicice et al., 2018), which could eventually lead to local population decline and even extinction.

The impoundment of rivers is known to have devastating effects on fish biology (Agostinho et al., 2016), in particular for migratory fish which are considered to be umbrella species for the protection of aquatic environments (Agostinho et al., 2005). The results of the present study provide important insights for the regulation of local $P$. hemioliopterus fisheries on the Xingu River, including a minimum catch size and a close season. These data are especially relevant to $P$. hemioliopterus, which is a species of high commercial value, and is also prized by sport fishers. However, the data cannot be extrapolated to the other migratory species of the Xingu basin, given that each fish has its own intrinsic characteristics, nor can it be extrapolated to the P. hemioliopterus stocks in other basins, given the distinct biological and geomorphological features of these systems. The findings of the present study nevertheless provide important insights for the development of effective conservation and management strategies for the fish populations impacted by the impoundment of the middle Xingu River, and potentially also for the Amazon basin as a whole.

\section{Acknowledgments}

The authors are grateful to Norte Energia and LEME for financial support. The collection of biological material was authorized by permit 057/2012 from Instituto Brasileiro de Meio Ambiente e de Recursos Naturais Renováveis (IBAMA). This study was financed in part by the Coordenação de Aperfeiçoamento de Pessoal de Nível Superior - Brasil (CAPES) - Finance Code 001 (TMSF - process 23038.042984/ 2008-30; LFAM - process 88881.119097/2016-01), and CNPq (LFAM - process 305017/2016-0). We also thank all the members of the IctioXingu CNPq Research Group. The English review was made by Dr. Stephen Ferraris.

\section{References}

Agência Nacional de Águas (ANA). Rede Hidrometeorológica Nacional. 2018. Available from: http://www.snirh.gov.br/ gestorpcd/Mapa.aspx

Agostinho AA, Gomes LC, Santos NCL, Ortega JCG, Pelicice FM. Fish assemblages in Neotropical reservoirs: colonization patterns, impacts and management. Fish Res. 2016; 173(1):26-36. Available from: https://doi.org/10.1016/j. fishres.2015.04.006

Agostinho AA, Gomes LC, Veríssimo S, Okada EK. Flood regime, dam regulation and fish in the Upper Paraná river: effects on assemblage attributes, reproduction and recruitment. Rev Fish Biol Fish. 2004; 14(1):11-19. Available from: https://doi. org/10.1007/s11160-004-3551-y

Agostinho AA, Thomaz SM, Gomes LC. Conservation of the biodiversity of Brazil's inland waters. Conserv Biol. 2005; 19(3):646-52. Available from: https://doi.org/10.1111/j.15231739.2005.00701.x

Antonio RR, Agostinho AA, Pelicice FM, Bailly D, Okada EK, Dias JHP. Blockage of migration routes by dam construction: can migratory fish find alternative routes? Neotrop Ichthyol. 2007; 5(2):177-84. Available from: http://dx.doi.org/10.1590/ S1679-62252007000200012

Bailly D, Agostinho AA, Suzuki HI. Influence of the flood regime on the reproduction of fish species with different reproductive strategies in the Cuiabá river, Upper Pantanal, Brazil. River Res Appl. 2008; 24(9):1218-29. Available from: https://doi. org/10.1002/rra.1147

Barbarino-Duque A, Winemiller KO. Dietary segregation among large catfishes of the Apure and Arauca rivers, Venezuela. J Fish Biol. 2003; 63(2):410-27. Available from: https://doi. org/10.1046/j.1095-8649.2003.00163.x

Barbosa TAP, Benone NL, Begot TOR, Gonçalves A, Sousa L, Giarrizzo T, et al. Effect of waterfalls and the flood pulse on the structure of fish assemblages of the middle Xingu river in the eastern Amazon basin. Braz J Biol. 2015; 75(3):78-94. Available from: http://dx.doi.org/10.1590/1519-6984.00214BM

Barbosa TAP, Rosa DCO, Soares BE, Costa CHA, Esposito MC, Montag LFA. Effect of flood pulses on the trophic ecology of four piscivorous fishes from the eastern Amazon. J Fish Biol. 2018; 93(1):30-39. Available from: https://doi.org/10.1111/ jfb. 13669 
Barletta M, Cussac VE, Agostinho AA, Baigún C, Okada EK, Catella AC, et al. Fisheries ecology in South American river basins. In: Craig JF, editor. Freshwater Fisheries Ecology. New York: John Wiley \& Sons; 2015. p.311-348.

Barneche DR, Robertson DR, White CR, Marshall DJ. Fish reproductive-energy output increases disproportionately with body size. Science. 2018; 360(6389):642-45. Available from: http://dx.doi.org/10.1126/science.aao6868

Barthem RB, Goulding M. The catfish connection: ecology, migration, and conservation of Amazon predators. New York: Columbia University Press; 1997.

Barthem RB, Goulding M. An unexpected ecosystem. The Amazon as revealed by fisheries. Saint Louis: Missouri Botanical Garden Press; 2007.

Barthem RB, Goulding M, Leite RG, Cañas C, Forsberg B, Venticinque E, et al. Goliath catfish spawning in the far western Amazon confirmed by the distribution of mature adults, drifting larvae and migrating juveniles. Sci Rep. 2017; 7(41784):1-13. Available from: https://dx.doi.org/10.1038/srep41784

Barzotto E, Oliveira M, Mateus L. Reproductive biology of Pseudoplatystoma corruscans (Spix and Agassiz, 1829) and Pseudoplatystoma reticulatum (Eigenmann and Eigenmann, 1889), two species of fisheries importance in the Cuiabá River basin, Brazil. J Appl Ichthyol. 2017; 33(1):29-36. Available from: https://doi.org/10.1111/jai.13162

Bisazza A, Pilastro A. Small male mating advantage and reverse size dimorphism in poecillid fishes. J Fish Biol. 1997; 50(2):397406. Available from: https://doi.org/10.1111/j.1095-8649.1997. tb01367.x

Brasil, Ministério da Pesca e Aquicultura e Ministério do Meio Ambiente. Instrução Normativa Interministerial MPA/MMA n ${ }^{\circ}$ 12, de 25 de outubro de 2011 [Internet]. 2011a. Available from: http://www.icmbio.gov.br/cepsul/images/stories/legislacao/ Instrucao_normativa/2011/ini_mpa_mma_12_2011_ regulamentopescanabaciahidrograficarioaraguaia.pdf

Brasil, Ministério da Pesca e Aquicultura e Ministério do Meio Ambiente. Instrução Normativa Interministerial MPA/MMA n ${ }^{\circ}$ 12, de 25 de outubro de 2011 [Internet]. 2011b. Available from: http://www.icmbio.gov.br/cepsul/images/stories/legislacao/ Instrucao_normativa/2011/ini_mpa_mma_13_2011_ regulamentapescabaciahidrograficariotocantins_gurupi.pdf

Bromley PJ. The use of market sampling to generate maturity ogives and to investigate growth, sexual dimorphism and reproductive strategy in central and south-western North Sea sole (Solea solea L.). ICES J Mar Sci. 2003; 60(1):52-65. Available from: https://doi.org/10.1006/jmsc.2002.1318

Carolsfeld J, Harvey B, Ross C, Baer A. Migratory fishes of South America: biology, fisheries and conservation status. Washington DC; Victoria BC; Ottawa CA: The World bank, World Fisheries Trust and The International Development Research Centre; 2003.

De Chambrier A, Rego AA, Pertierra AGD. Redescription of two cestodes (Eucestoda: Proteocephalidea) parasitic in Phractocephalus hemioliopterus (Siluriformes) from the Amazon and erection of Scholzia gen. n. Rev Suisse Zool. 2005; 112:735-52.

Fricke R, Eschmeyer WN, van der Laan R. Eschmeyer's Catalog of fishes: genera, species, references. San Francisco: California Academy of Science; 2019. Available from: (http://researcharchive. calacademy.org/research/ichthyology/catalog/fishcatmain.asp)
Figueiredo RS, Viana LF, Moraes DP, Súarez YR. Life-history traits of Farlowella hahni (Siluriformes, Loricariidae) in streams of the Ivinhema River basin, Upper Paraná basin. Braz J Biol. 2018; 79(2):286-93. Available from: http://dx.doi. org/10.1590/1519-6984.181073

Fontoura NF, Agostinho AA. Growth with seasonally varying temperatures: an expansion of the von Bertalanffy growth model. J Fish Biol. 1996; 48(4):569-84. Available from: https:// doi.org/10.1111/j.1095-8649.1996.tb01453.x

Fontoura NF, Braun AS, Milani PCC. Estimating size at first maturity (L50) from Gonadossomatic Index (GSI) data. Neotrop Ichthyol. 2009; 7(2):217-22. Available from: http:// dx.doi.org/10.1590/S1679-62252009000200013

Fontoura NF, Conter MR. Description of a new subspecies of the crayfish Parastacus brasiliensis (Von Martens, 1869) from São Francisco de Paula, RS, Brazil (Decapoda, Parastacidae). Zootaxa. 2008; 1849:28-34.

Forsberg BR, Melack JM, Dunne T, Barthem RB, Goulding M, Paiva RCD, et al. The potential impact of new Andean dams on Amazon fluvial ecosystems. PLOS ONE. 2017; 12(8):e0182254. Available from: https://doi.org/10.1371/ jornal.pone. 0182254

Freitas TMS, Almeida VHC, Montag LFA, Fontoura NF. Predicting size at first sexual maturity from length/weight relationship: a case study with an Amazonian catfish. Neotrop Ichthyol. 2016; 14(4):e150152. Available from: http://dx.doi. org/10.1590/1982-0224-20150152

Freitas TMS, Almeida VHC, Montag LFA, Rocha RM, Fontoura NF. Seasonal changes in the gonadossomatic index, allometric condition factor and sex ratio of an auchenipterid catfish from eastern Amazonia. Neotrop Ichthyol. 2011; 9(4):83947. Available from: http://dx.doi.org/10.1590/S167962252011005000044

Freitas TMS, Prudente BS, Oliveira VA, Oliveira MNC, Prata EG, Leão H, Montag LFA. Influence of the flood pulse on the reproduction of Tocantinsia piresi (Miranda Ribeiro) and Auchenipterus nuchalis (Spix \& Agassiz) (Auchenipteridae) of the middle Xingu River, Brazil. Braz J Biol. 2015; 75(3):158-67. Available from: http://dx.doi.org/10.1590/15196984.00114BM

Froese R. Cube law, condition factor and weight-length relationships: history, meta-analysis and recommendations. J Appl Ichthyol. 2006; 22(4):241-53. Available from: https://doi. org/10.1111/j.1439-0426.2006.00805.x

García-Vasquéz A, Alonso JC, Carvajal F, Moreau J, Nuñez J, Renno $\mathrm{JF}$, et al. Life-history characteristics of the large Amazonian migratory catfish Brachyplatystoma rousseauxii in the Iquitos region, Peru. J Fish Biol. 2009; 75(10):2527-51. Available from: https://doi.org/10.1111/j.1095-8649.2009.02444.X

Giarrizzo T, Sena-Oliveira RR, Andrade MC, Gonçalves AP, Barbosa TAP, Martins AR, et al. Length-weight and lengthlength relationships for 135 fish species from the Xingu River (Amazon basin, Brazil). J Appl Ichthyol. 2015; 31(2):415-24. Available from: https://doi.org/10.1111/jai.12677

Godinho AL, Kynard B. Migratory fishes of Brazil: Life history and fish passage needs. River Res Appl. 2009; 25(6):702-12. Available from: https://doi.org/10.1002/rra.1180

Goulding M. The fishes and the forest: explorations in Amazonian natural history. California: University of California Press; 1980. 
Hahn L, Nunes LD, Câmara LF, Machado LS, Abolis D, Fries LCC, et al. Reporting on the recapture of electronic tagged fish by fishers in the Xingu River, Brazilian Amazon. Braz J Biol. 2015; 75(3):99-101. Available from: http://dx.doi. org/10.1590/1519-6984.02214BM

Hauser M, Doria CRC, Melo LRC, Santos AR, Ayala DM, Nogueira LD, et al. Age and growth of the Amazonian migratory catfish Brachyplatystoma rousseauxii in the Madeira River basin before the construction of dams. Neotrop Ichthyol. 2018; 16(1):e170130. Available from: http://dx.doi. org/10.1590/1982-0224-20170130

Holzbach AJ, Gubiani EA, Baumgartner G. Iheringichthys labrosus (Siluriformes: Pimelodidae) in the Piquiri River, Paraná, Brazil: population structure and some aspects of its reproductive biology. Neotrop Ichthyol. 2009; 7(1):55-64. Available from: http://dx.doi.org/10.1590/S1679-62252009000100008

International Union for Conservation of Nature (IUCN). The IUCN Red List of Threatened Species; Version 2019-1 [Internet]. 2019. Available from: http://www.iucnredlist.org

Järvi TH. Die kleine Maräne (Coregonus albula L.) im Keitelesee, eine ökologische und ökonomische studie. Helsinki: Suomalainen Tiedeakatemia; 1920.

Junk W, Bayley PB, Sparks RE. The flood pulse concept in riverfloodplain systems. In: Dodge DP, editor. Ontario: Proceedings of the International large River Symposium; 1989. p.110-127.

Lundberg JG, Littmann MW. Family Pimelodidae (Longwhiskered catfishes). In: Reis RE, Kullander SO, Ferraris CJ, editors. Checklist of the freshwater fishes of South and Central America. Porto Alegre: EDIPUCRS; 2003. p.432-446.

Mesquita EMC, Isaac-Nahum VJ. Traditional knowledge and artisanal fishing technology on the Xingu River in Pará, Brazil. Braz J Biol. 2015; 75(3):138-57. Available from: http://dx.doi. org/10.1590/1519-6984.01314BM

Murua H, Saborido-Rey F. Female reproductive strategies of marine fish species of the North Atlantic. J Northw Atl Fish Sci. 2003; 33:23-31.

Paschoalini AL, Perini VR, Ribeiro DM, Formagio PS, Rizzo E, Bazzoli N. Reproduction of Pimelodus maculatus (Siluriformes: Pimelodidae) in three section of Grande River basin, downstream Porto Colombia dam, south-eastern Brazil. Neotrop Ichthyol. 2013; 11(3):615-23. Available from: http:// dx.doi.org/10.1590/S1679-62252013000300015

Peel MC, Finlayson BL, McMahon TA. Updated world map of the Köppen-Geiger climate classification. Hydrol Earth Syst Sci. 2007; 4(2):439-73.

Pelicice FM, Azevedo-Santos VM, Esguícero ALH, Agostinho AA, Arcifa MS. Fish diverstity in the cascade of reservoirs along the Paranapanema River, southeast Brazil. Neotrop Ichthyol 2018; 16(2):e170150. Available from: http://dx.doi.org/10.1590/19820224-20170150

Pérez A, Fabré NN. 2018. Life-history characteristics of Pseudoplatystoma metaense (Teleostei: Siluriformes: Pimelodidae) from the northwestern Orinoco River basin. Neotrop Ichthyol. 2018; 16(1):e160140. Available from: http:// dx.doi.org/10.1590/1982-0224-20160140
Prudente BS, Ferreira MAP, Rocha RM, Montag LFA. Reproductive biology of the piranha Serrasalmus gouldingi (Fink and Machado-Allison 1992) (Characiformes: Serrasalmidae) in "drowned" rivers of the eastern Amazon. Environ Biol Fish. 2014; 98(1):11-22. Available from: https://doi.org/10.1007/ s10641-014-0232-0

R Development Core Team. R: a language and environment for statistical computing [Computer software manual - Internet]. Vienna: R Foundation for Statistical Computing; 2015. Available from: https://www.R-project.org/

Sarmiento J, Bigorne R, Carvajal-Vallejos FM, Maldonado M, Oberdorff T, editors. Peces de Bolivia/Bolivian Fishes. La Paz: Plural Editores; 2014.

Suzuki FM, Garcia DAZ, Orsi ML. Reproductive Dynamics of Iheringichthys labrosus (Lütken, 1874) (Teleostei, Pimelodidae), in the Capivara Reservoir, Paranapanema River, Parana, Brazil. Dataset Pap Biol. 2013; 2013:1-6. Available from: http://dx.doi.org/10.7167/2013/607541

Swarça AC, Dias AL, Fenocchio AS. Cytogenetic studies in the redtail catfish, Phractocephalus hemioliopterus (Bloch \& Schneider, 1801) (Siluriformes, Pimelodidae) a giant fish from Amazon basin. Comp Cytogenet. 2017; 11(1):119-28. Available from: https://dx.doi.org/10.3897\%2FCompCytogen.v11i1.11152

Tiago GG. Ementário da legislação de aquicultura e pesca do Brasil. 3rd ed. São Paulo; 2011.

Trippel EA. Age at maturity as a stress indicator in fisheries. BioScience. 1995; 45(11):759-71. Available from: https:// www.jstor.org/stable/1312628

Trippel EA, Harvey HH. Comparison of methods used to estimate age and length of fishes at sexual maturity using populations of white sucker (Catostomus commersoni). Can J Publ Fish Aquat Sci. 1991; 48(8):1446-59. Available from: https://doi. org/10.1139/f91-172

Vazzoler AEAM. Biologia da reprodução de peixes teleósteos: Teoria e prática. Maringá: EDUEM; 1996.

Veloso-Junior VC, Arantes FP, Santos JE. Population structure and reproduction of the Neotropical catfish Pimelodus pohli, Ribeiro and Lucena, (Teleostei: Pimelodidae). J Appl Ichthyol. 2014; 30(2):399-402. Available from: https://doi.org/10.1111/jai.12270

Winemiller KO, McIntyre PB, Castello L, Fluet-Chouinard E, Giarrizzo T, Nam S, et al. Balancing hydropower and biodiversity in the Amazon, Congo, and Mekong. Science. 2016; 351(6269):128-29. Available from: https://doi. org/10.1126/science.aac 7082

Zar JH. Biostatistical analysis. 5th ed. New Jersey: Prentice Hall; 2010.

Zeug SC, Winemiller KO. Relationships between hydrology, spatial heterogeneity, and fish recruitment dynamics in a temperate floodplain river. River Res Appl. 2008; 24(1):90-102. Available from: https://doi.org/10.1002/rra.1061

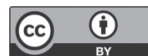

Submitted December 09, 2017 Accepted May 20, 2019 by Elizete Rizzo 